\title{
Toll-Managed Lane Pioneers: LeSSONS FROM FiVe US STATES
}

\author{
Emily Swimmer, ${ }^{1}$ Carter B. Casady ${ }^{2 *}$, and Jose A. Gomez-Ibanez ${ }^{3}$
}

\begin{abstract}
Toll-managed lanes have become an increasingly popular technique among transportation policymakers for managing congestion on existing highways and, in some cases, financing the construction of new lanes in congested urban corridors. Although growing in popularity, the adoption of these facilities is concentrated in five states: Texas, California, Colorado, Minnesota, and Florida. This paper examines the adoption and utilization of toll-managed lanes in these pioneer states. Using archival, case-based research, our analysis suggests that the adoption of toll-managed lanes was driven by a combination of factors, including rapid population growth, near or above average growth in vehicle miles traveled (VMT), and insufficient gas tax funding for transportation investments. Implementation was also generally similar across states but some of the pioneers delegated the management of their toll-managed lane programs to special regional highway authorities while others used state highway agencies.
\end{abstract}

\section{KEYWORDS}

Managed lanes; transportation; public-private partnerships (PPPs); tolls; case studies

\footnotetext{
${ }^{1}$ Master of Urban Planning, Harvard University, USA, 925-322-3835, emarsh@gsd.harvard.edu

${ }^{2} \mathrm{PhD}$ Candidate, Civil and Environmental Engineering, Stanford University, USA, 310-592-8163, cbcasady@stanford.edu; *Corresponding author

${ }^{3}$ Professor, Urban Planning and Public Policy, Harvard University, USA, 617-495-1341, jose gomezibanez@hks.harvard.edu
} 


\section{INTRODUCTION}

Toll-managed lanes are lanes which operate adjacent to the general-purpose lanes of an expressway to optimize traffic capacity, free flow speeds, and/or trip reliability (FHWA 2012; FHWA 2017b). Access to toll-managed lanes is usually restricted by vehicle type and/or occupancy, special lane entrances and exits (e.g. express, contraflow or reversible), and tolls/congestion charges which vary according to traffic patterns throughout the day.

Toll-managed lanes typically take one of two distinct forms. The first type utilizes tolling largely to regulate congestion rather than to finance facility expansion. This type is often the product of the conversion of existing and underutilized High Occupancy Vehicle (HOV) lanes to High Occupancy Toll (HOT) lanes. Used to primarily manage congestion, these HOT lane conversions restrict access to toll-paying motorists and high occupancy vehicles, such as carpools or buses, who received a toll discount or exemption.

The second type of toll-managed lanes are designed to raise revenue to finance lane construction as well as control congestion. These toll-managed lanes typically do not allow high-occupancy vehicles discounted or free access to the lanes. Moreover, because purposebuilt managed lanes are usually very costly, private concessionaires are sometimes contracted via public-private partnerships (PPPs) to build, finance, and operate these facilities for a fixed term, usually of 30 to 50 years (FHWA 2016a). In either form, toll-managed lanes that are appropriately planned and implemented can reduce congestion and deliver faster travel times.

The congestion-relief benefits of toll-managed lanes were first demonstrated in the US when the State Route (SR)-91 Express Lanes in California opened in the early 1990s. Although the concept of tolling lanes had already been around for decades, SR-91 kindled the interest in managed lanes as viable, toll-based congestion management technique. After California's legislature passed legislation in 1989 which enabled California's Department of Transportation (Caltrans) to contract with private concessionaires and collect tolls from motorists on expressways, SR-91 was built by private investors alongside and within the existing right-ofway of the SR-91 freeway. The $\$ 125$ million, ten-mile facility was awarded by the State of California as a build, own, operate concession for 35 years. The original contract prohibited adding capacity to the adjacent SR-91 facility in an effort to eliminate competition. This lead to the buyout of investors by Orange County before the contract termed but the SR-91 managed lanes generated, at their peak, upwards of $\$ 40$ million in revenue per year.

Since the opening of SR-91, transportation policy makers across the United States have increasingly used toll-managed lanes to improve the use of road capacity on existing expressways and/or finance the construction of new lanes in congested urban corridors (Pool 2014; Fitch 2018). While only two additional managed lane projects were deployed in the United States within the first ten years after the opening of SR-91, by 2010, the number in operation had increased to nine. By 2018, this number had exploded to 48 (see Figure 1).

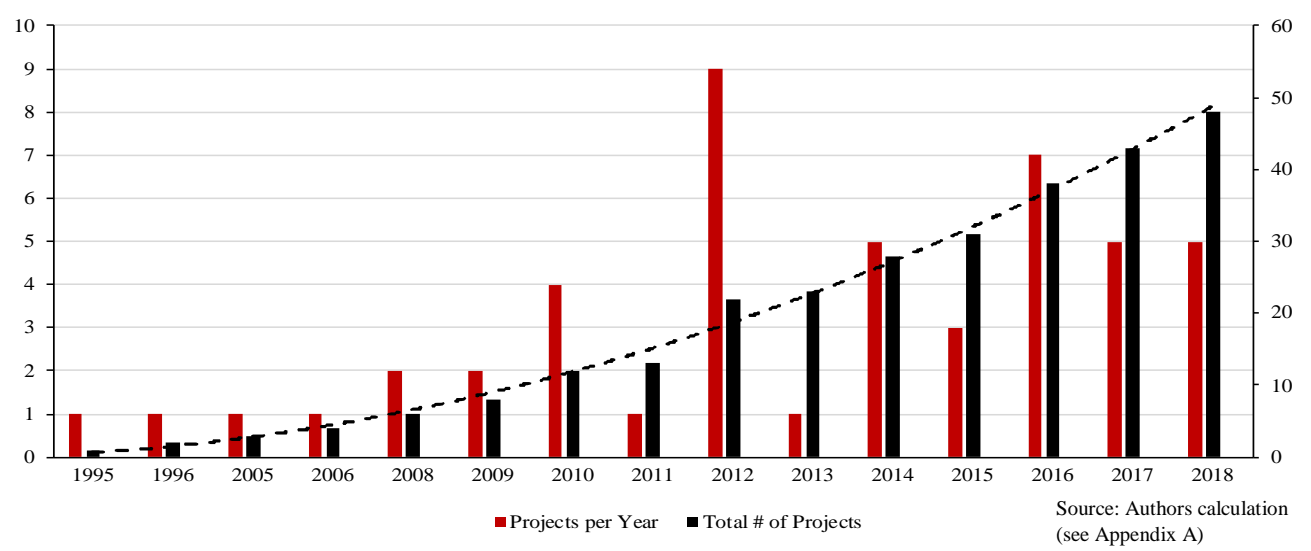

Figure 1: HOT Lane Facility Openings in US (1995 - 2018) 
To date, many more projects are currently in planning or under construction (see Appendix A).

Additionally, the early adoption of managed lane facilities was primarily concentrated in five states: namely Texas, California, Colorado, Florida, and Minnesota (see e.g. TRB 2019). As the utilization of managed lanes expands to other states, it is important to reflect on how these five pioneer states embraced the managed lane concept. In this paper, we thus aim to address the following research question:

(1) What economic, political, and social factors motivated the adoption of toll-managed lanes in these pioneer states?

In the following section, we begin with a brief history of toll-managed lanes in the United States. Next, we examine the adoption of toll-managed lanes in the five pioneer states. Finally, we provide a short discussion of the similarities and differences in toll-managed lane implementation among these states.

\section{A BRIEF History OF TOLL-MANAGED LANES}

For almost a century, federal and state motor fuel taxes have been the major source of funding for highway construction and maintenance. In 1956, Congress established the Interstate and Defense Highway System, a road network of 32,000 miles to be built and maintained by the states with the inducement of federal grants to cover 90 percent of the construction cost. The grants were funded by a federal tax on fuels, and Congress prohibited the states from collecting tolls on the Interstates on the grounds that motorists had already paid for them through the federal fuels tax. The only exceptions were roughly a dozen toll roads in the East that were grandfathered into the Interstate System. At the state level, there was also popular resistance to tolling state highways that were not part of the Interstate System on similar grounds.

As traffic increased on the Interstate System, transportation policy makers began deploying HOV lanes to manage growing congestion. While HOV facilities were first deployed in World War II as part of a fuel rationing program, they did not reappear until the energy crises of the early 1970s as exclusive bus lanes (FHWA 2016b, 2017a). The pioneers included a bus-only lane on the Shirley Highway in northern Virginia and contra-flow bus lanes on the approaches to the Lincoln Tunnel between New York and New Jersey. In many cases, the bus lanes increased public transit ridership, as intended, but not enough to use more than a small fraction of the lane's vehicle carrying capacity. Motorists stuck in the congested general-purpose lanes were often angered to observe only a few buses per minute whiz by in the adjacent bus lane. To improve utilization, the bus lanes were initially opened to carpools of three or more people (HOV3+) and later, if there was still capacity, to carpools of two or more (HOV2+). These changes saw "many HOV lanes ... outperform adjacent general-purpose highway lanes in terms of person throughput, especially during peak hours of service" (FHWA 2017a, 1-1). However, large portions of America's 2,500 lane-mile HOV network still experienced "mild to severe underutilization or overcrowding or both, depending of prevailing traffic conditions" (FHWA 2017a, 2-1).

With HOV lanes "not meet[ing] expectations about congestion relief benefits," interest in tolling revived in the 1980s and 1990s (FHWA 2017a, 1-1). By then, the Interstate System was essentially complete but state and local governments were looking for sources of revenue to fund the rehabilitation of older segments as well as the extension of expressways to areas where the original Interstate planners had not anticipated development. Anti-tax sentiment in the 1980s made it increasingly difficult to raise federal or state fuel taxes, even though the proceeds were often earmarked for transportation. Moreover, transportation planners were becoming 
increasingly interested in the potential for using pricing (e.g. tolls) to manage severe congestion on existing highways instead of building costly new capacity.

Over the last decade or two, Congress has relaxed restrictions for tolling on Interstate highways to some degree. For example, with special permissions from FHWA programs, tolls can now be collected on bridges that are being rebuilt, applied to HOV lane conversions, and used when existing Interstates are rebuilt and/or widened as long as the number of un-tolled lanes is not reduced. When coupled with the development and spread of electronic toll collection and video enforcement technologies, these relaxed restrictions have enabled transportation planners to explore new active demand management (ADM) techniques. While ADM encompasses a variety of different ways to "[use] information and technology to dynamically manage demand" by time of day or by actual levels of congestion in order to maintain free flow speeds (FHWAb 2017b) ${ }^{4}$, toll-managed lanes-i.e. high occupancy toll (HOT) lanes, Express Toll Lanes (ETLs), Value Pricing Lanes, and smart roads - have become one of the most popular ADM strategy among transportation agencies in recent years. Although toll-managed lanes initially got off to a slow start after their practical demonstration in California on SR-91, an average of roughly five new facilities opened per year between 2010 and 2018. Today, most operating toll-managed lanes remain concentrated in our five pioneering states. ${ }^{5}$

\section{Case Analysis: Pioneer States in Toll-Managed lane Adoption}

We utilize a case study research design to help us understand why and how these states became toll-managed lane pioneers (Yin 2017). We rely on archival records from various mediums, including academic manuscripts, government reports, news articles, databases, and other print/online sources. Our approach remains exploratory given that time and space requirements preclude us from providing an overly detailed historical account of toll-managed lane adoption in these five pioneer states. Finally, because the vast majority of today's currently operating managed lane facilities opened prior to 2017 and many new project have been extensions of existing facilities, our case analysis focuses primarily on the formative years of managed lane adoption (i.e. 1995 - 2016) rather than more current developments in each state (i.e. 2017 2019).

\subsection{TEXAS}

By the early 2000s, Texas faced increasing highway maintenance and construction needs as its metropolitan populations grew while the overall revenue from the state's gas tax declined due to inflation and improving fuel efficiency of cars (Williamson 2010). Because raising the gas tax was not a politically viable option, Texas sought alternative methods for delivering needed highway improvement projects, including both reconstruction and expansion of existing highways and construction of new highways. In 2000, the Texas Transportation Institute, with support from the Texas Department of Transportation (TxDOT) and FHWA, launched a study to provide preliminary guidance on how to plan and operate managed lanes in Texas. In 2003, the legislature passed several bills that authorized Texas transportation agencies to create HOT lanes and to pursue alternative financing mechanisms (Kuhn et al. 2005). Most notably, House Bill 3588 enabled transportation agencies to use new financing mechanisms aimed at accelerating project delivery and generating additional cash flow, which included comprehensive development agreements with private entities. This allowed private entities to

\footnotetext{
4 Other ADM strategies include dynamic fare reduction, dynamic HOV lanes, dynamic pricing, dynamic ridesharing, dynamic routing, and dynamic transit capacity assignment as well as on-demand transit, predictive traveler information, and transfer connection protection (FHWA 2017b).

${ }^{5}$ Within the last two years, Georgia has added a few additional corridors to its network. They are not one of our pioneer cases.
} 
fully design, build, operate, and finance toll roads. Further, the bill authorized the Texas Transportation Commission to create regional mobility authorities (RMAs) to enable localities to approve and generate revenue from regional transportation projects. Revenue from these projects could also be used to fund future infrastructure investments (Ellis et al. 2014).

Before the passage of the legislation in 2003, the Katy Freeway (Interstate Highway 10), a highly congested freeway in Houston, had already been assessed as obsolete by TxDOT with, "maintenance costs at four times the average expressway segment and inadequate to carry the 200,000 vehicles daily demand" (Goodin et al. 2013). In 1998, in advance of HOT lanes legislation, TxDOT piloted a QuickRide Program, which allowed single occupancy vehicles to use the HOV lanes for $\$ 2$ per trip. The pilot was effective in relieving congestion in the generalpurpose lanes and provided customers with a choice of how to travel during commute hours. Given the limited available transportation funds and recent Texas legislation, TxDOT elected to implement HOT lanes on the Katy Freeway in order to fully

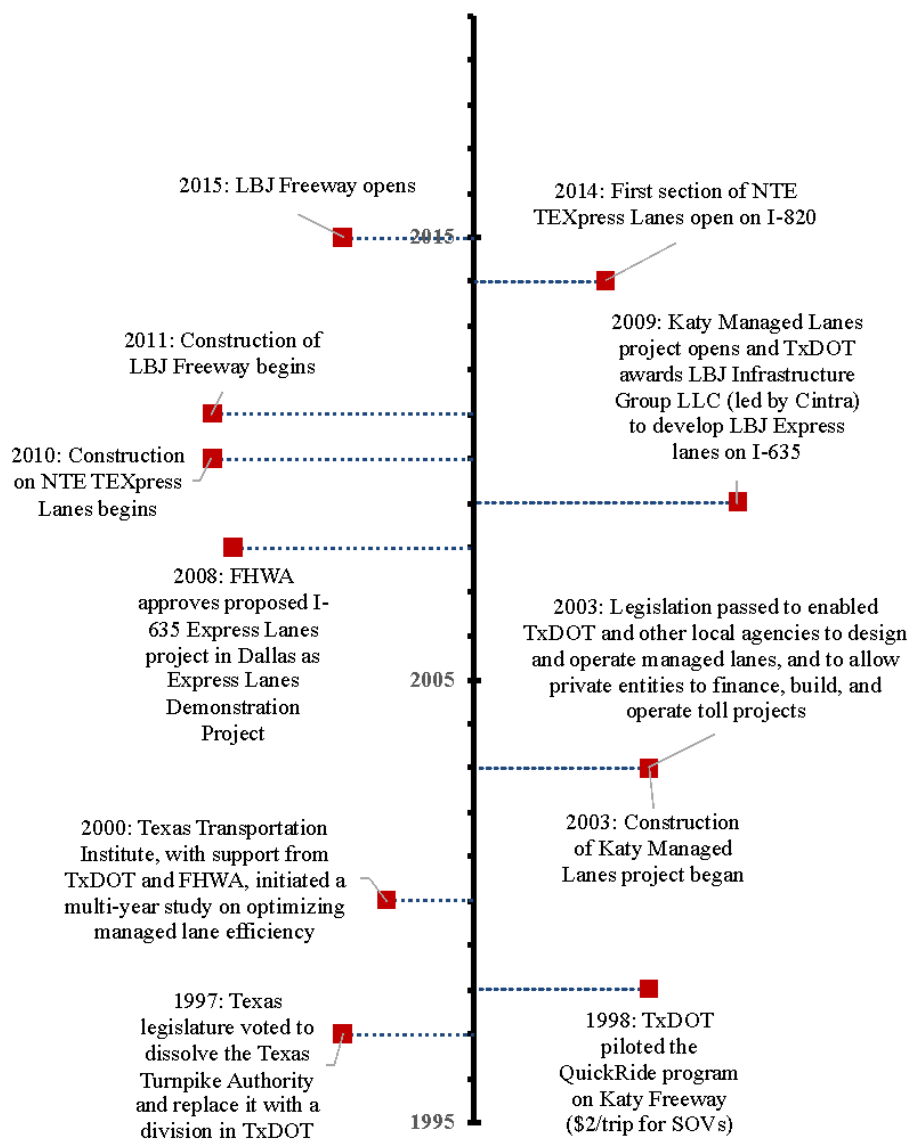

Figure 2: Texas' Initial Managed Lane Milestones reconstruct a 12-mile portion of the roadway. The Metropolitan Transit Authority of Harris County (METRO) assumed responsibility for financing, constructing, operating and maintaining the managed lanes portion of the freeway, while TxDOT maintained responsibility for operating the general-purpose lanes (Goodin et al. 2013). The Harris County Toll Road Authority (HCTRA) then joined this partnership between TxDOT and METRO and implemented three HOT lane projects in the Houston metropolitan region. It also extended two of these facilities.

HOT lanes projects have also become common in the Dallas area. These projects, however, are primarily being implemented through PPPs. The history of HOT lanes in north Texas begins with the Texas Turnpike Authority (TTA), which was formed in 1953 to construct and operate the Dallas-Fort Worth Turnpike. Although, the agency was tasked with constructing toll roads throughout Texas, the bulk of its projects were constructed in the Dallas-Fort Worth metropolitan region. In 1997, Senate Bill 370 converted the TTA, which had been an independent state agency, into a division of TxDOT. The same bill established the North Texas Tollway Authority (NTTA) as the regional toll authority and transferred all of TTA's assets 
and liabilities to the NTTA. ${ }^{6}$ As the local toll authority, NTTA is tasked with financing, constructing, and overseeing turnpike projects in the region. Under Senate Bill 370, NTTA has the first option to develop planned toll roads. When it is not feasible for NTTA to construct a toll road, however, the agency may waive its primacy (NTTA 2017), which it did in the cases of the Dallas' North Tarrant Expressway and LBJ Freeway.

By the early 2000s, the 10-lane LBJ Freeway (I-635) in Dallas reached its peak capacity of 270,000 vehicles per day and TxDOT estimated that demand would eventually increase to 500,000 vehicles per day. The roadway needed to be expanded, but, given limited public funding, there was a risk that the project would be delayed or never built (Williamson 2013). TxDOT submitted a proposal for the LBJ Freeway to be included in FHWA's Express Lanes Demonstration Project, which was approved in 2008 and allowed TxDOT to manage congestion on the aging LBJ Freeway using HOT lanes. Due to limited public funding, TxDOT elected to rebuild the freeway as a PPP. TxDOT competitively awarded the contract, which includes a 50-year concession agreement, to the LBJ Infrastructure Group, led by Cintra, and construction began in 2011. In the same time period and for the same reasons, NTTA elected to relieve congestion on North Tarrant Expressway (I-820) by constructing HOT lanes along a 12-mile section. As with TxDOT and the LBJ Freeway, NTTA decided to construct this project, NTE TEXpress Lanes, as a PPP and awarded the contract to the NTE Mobility Partners, a consortium between Meridiam Infrastructure, Cintra $^{7}$, and North Tarrant Infrastructure LLC i.e. joint venture between Ferrovial Agroman US Corp. and Webber LLC). The first section of NTE TEXpress Lanes opened in 2014.

Since the initial reconstruction of the LBJ Freeway and NTE TEXpress Lanes, LBJ Infrastructure Group/NTE Mobility Partners has been implementing a system of HOT lane facilities across the Dallas-Fort Worth metropolitan region, including the expansion of the NTE TEXpress Lanes (Sanchez 2016; see also Appendix A). As of 2017, there were a total of four HOT lane facilities in the Dallas-Fort Worth Area with five more projects underway (four are facility extensions) (FHWA 2017c). In total, Texas has constructed over 130 miles of HOT lanes in the Houston, Dallas - Fort Worth, and Austin metropolitan regions since its first tollmanaged lane project opened in Houston in 2009. In Austin specifically, the Central Texas Regional Mobility Authority is slowly building out another network of managed lanes. To date, Austin has four operating facilities, three under construction, and three under development (see, e.g. CTRMA 2019). Like Austin, Texas' broader network of managed lanes continues to expand.

\subsection{FLORIDA}

The first toll-managed toll lane in Florida opened in 2008 on Interstate 95, which cuts through Miami-Dade, Palm Beach and Broward Counties. By 2014, the toll-managed lane on Interstate 95 had been extended twice and now totals 22 miles. As of 2017, Florida is constructing four additional toll-managed lane projects on three new facilities, two of which are in Miami-Dade County and the other two in Northeast and Central Florida (FHWA 2017c). Florida is also in the planning stages for two additional projects in Tampa and Northeast Florida.

The groundwork for toll-managed lanes in Florida began in 2002 when Governor Jeb Bush signed House Bill 261, which created Florida's Turnpike Enterprise (FTE), a business unit of the Florida Department of Transportation (FDOT), to manage and operate tolled highways throughout Florida. Governor Bush directed the FTE "to pursue innovation and best private-

\footnotetext{
${ }^{6}$ NTTA was the only regional toll authority established in Texas as a result of this bill. In addition to this regional toll authority, Texas has seven county toll authorities (such as HCTRA) and eight regional mobility authorities that have a similar structure as the NTTA.

${ }^{7}$ Cintra is a subsidiary of Madrid-based Ferrovial.
} 
sector businesses practices, to improve cost-effectiveness and timeliness in project delivery, to increase revenues and expand its capital program, and to improve quality of service to its customers" (IPFS 2016). Florida's Office of Toll Operations was merged into the newly created FTE. In 2017, FTE managed 600 miles of roadway and 80 percent of all Florida tolled facilities.

In 2003, FDOT hired Robert Poole, toll-managed lane advocate and the founder of the Reason Foundation, to study the viability of toll lanes in South Florida. In 2008 Poole published a report titled "A Managed Lanes Vision for South Florida," which became "a primer for toll lane plans across the state" (Barton 2014). The report envisioned toll lanes throughout the Miami area by 2030. Poole's report

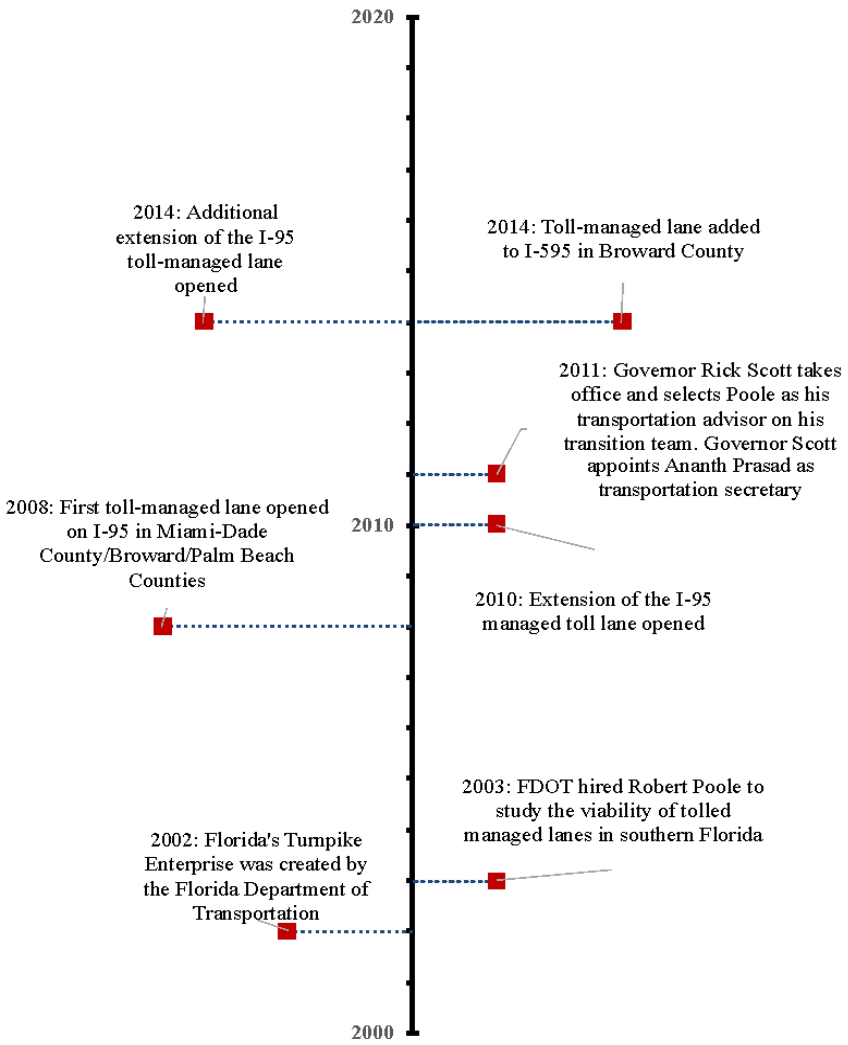

Figure 3: Florida's Initial Managed Lane Milestones specifically identified Interstate 95 as a candidate for a toll-managed lane because congestion during peak hours was so high that its single HOV lane was overcrowded with an average speed of $18 \mathrm{mph}$. FDOT, in partnership with USDOT and FTE, moved forward with this project and opened its first toll-managed lane on Interstate 95 in Miami in 2008 (see e.g. FDOT 2010, 2011, 2013). Although I-95 was implemented by FDOT rather than the then newly-created FTE, this first toll-managed lane project was put forth because FDOT, like FTE, was seeking alternative strategies for addressing increasing congestion and funding new capital projects.

When Governor Rick Scott was elected in 2011, he selected Poole as a transportation advisor for his transition team. With the success of the I-95 project and revenue from gas taxes on the decline, toll-managed lanes were solidified as Florida's strategy for transportation funding. Poole expanded on his 2008 managed lanes report and published a second report outlining a network of toll lanes in southeast Florida connecting Miami-Dade, Broward, and Palm Beach counties. As of 2017, the state was pushing ahead with plans to toll portions of Interstate 4 in Orlando, Interstates 275 and 75 in Tampa and extend the existing toll facilities on Interstate 95 in Miami into Broward County (Hannan 2012).

\subsection{MinneSOTA}

Minnesota opened its first toll-managed lane on Interstate 394 in 2005 (FHWA 2010). Minnesota opened its second managed toll lane project on Interstate 35W in 2009 and its third project on Interstate 35E in 2016. As of 2017, Minnesota's network of express lanes, called MnPass, includes 60-lane miles of roadway (FHWA 2017c).

I-394 became a candidate for toll-managed lanes in 2001 when a study completed by the Minnesota Department of Transportation (MnDOT) found that the highway's existing HOV lane was underused while the general-purpose lanes were becoming increasingly congested 
(Buckeye and Munnich 2006; Buckeye 2012). The study concluded that converting the HOV lane to a general-purpose lane would not be cost-effective and would ultimately increase congestion. Conversion to HOT lanes, on the other hand, would be both cost-effective and congestionreducing.

In 2003, after nearly a decade of controversy, the Minnesota Legislature enacted HOT Lane legislation, which authorized the MnDOT commissioner to implement user fees on HOV lanes. As in other states, the legislation won support as a result of growing highway congestion and declining gas tax revenue. In 2005, MnDOT launched the MnPass project with the primary goals of 1) improving the efficiency of I-394 by increasing the carrying capacity of HOV lanes, in terms of both individuals and vehicles, and 2) maintaining free-flow speeds (45 $\mathrm{mph}$ ) for transit and carpools in the express lanes (MnDOT 2005). Once opened, the new HOT lanes added 30 percent more trips to the previously underutilized HOV lanes.

The 2003 legislation also directed

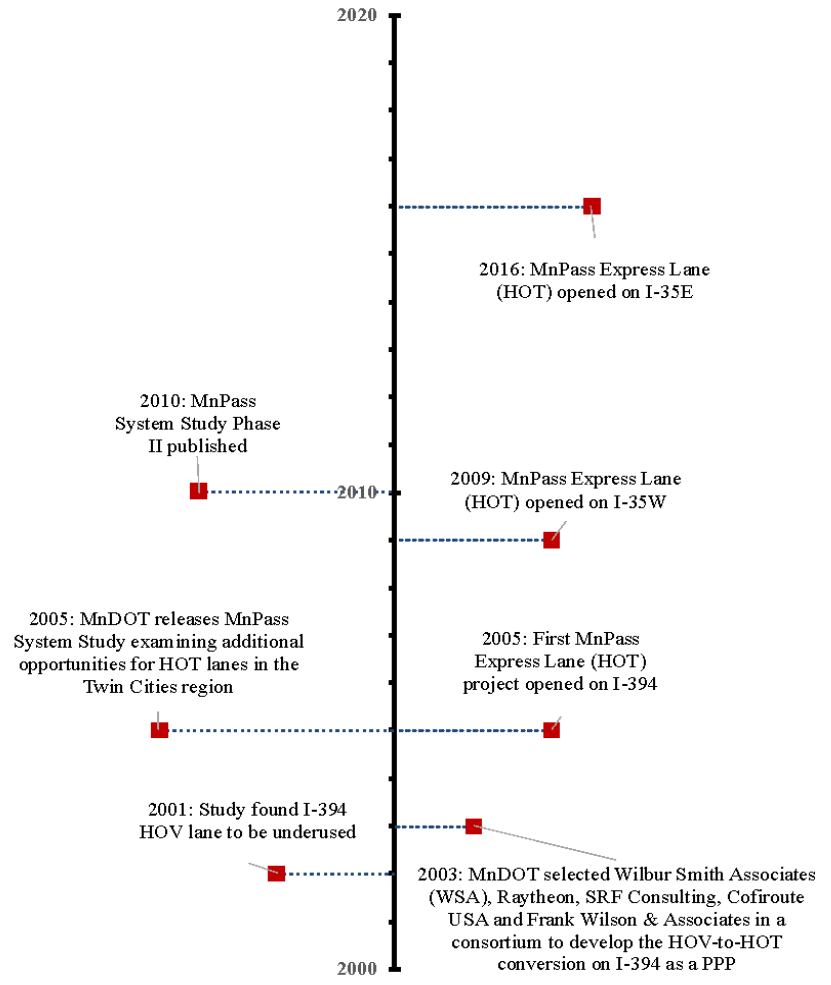

Figure 4: Minnesota’s Initial Managed Lane Milestones MnDOT to prepare a MnPASS system study to examine the "impacts of overlaying a MnPass toll lane system in the Twin Cities metropolitan region of Minneapolis and St. Paul" with the primary objective of identifying a regional tolling system (MnPass System Study, 2005). In 2007, MnDOT was awarded \$133.3 million for congestion management and transit projects from the USDOT as part of the Urban Partnership Program. Following the success of I-394 and the MnPass system study findings, MnDOT used a portion of this funding, which included $\$ 50$ million in state-matched funding, to convert and construct HOT lanes on I-35W and I-35E (USDOT 2013; Buckeye 2014). These projects opened in 2009 and 2016, respectively.

A second phase of the MnPass system study was completed in 2010 and evaluated whether one could design and build a less expensive MnPASS system that still provided significant benefits. The result was a list of MnPASS expansion priorities, which was adopted into the Metropolitan Council's 2040 Transportation Policy Plan (TPP) as the vision for the development of the MnPASS system (MnDOT 2010). Since the completion of the MnPASS System Study Phase 2, the MnPASS transportation system has expanded, and a Phase 3 study recently established a set of screening criteria for a new list of corridors for consideration in the 2040 TPP (MnDOT 2017).

\footnotetext{
${ }^{8}$ The Metropolitan Council (Met Council) is the metropolitan planning organization (MPO) for the Twin Cities region.
} 


\subsection{Colorado}

Like all states, Colorado's road infrastructure has been funded primarily by gas taxes, but Colorado residents had not voted to increase gas taxes since 1993. Colorado began considering toll-managed lanes in 2002 with the creation of the Colorado Tolling Enterprise (CTE), a division of the Colorado Department of Transportation (CDOT). Through CTE, the state sought to identify toll road opportunities in order to provide additional revenue to fund increased highway capacity and transportation infrastructure in the rapidly growing Denver area (CTE 2005). Specifically, the purpose of CTE was to "finance, construct, operate, regulate, and maintain a system of tolled highways in Colorado" (CDOT 2005).

In 2003, CTE initiated a statewide traffic and revenue feasibility analysis to identify potential toll projects based on financial feasibility. The analysis found that revenue from HOT lanes on I-25 near Denver would be able to fully fund the cost to convert the HOV lanes, as well as additional transportation improvements. The analysis also identified I-70, US-36, and C-470 as potential HOT corridors that would offer similar financial benefits (CTE 2004). As a result of this study, CDOT, along with CTE and local agencies, converted the I-25 HOV lanes to reversible HOT lanes, which opened in 2006. This first HOT lane project was developed and financed by the Colorado Department of Transportation (CDOT) using the

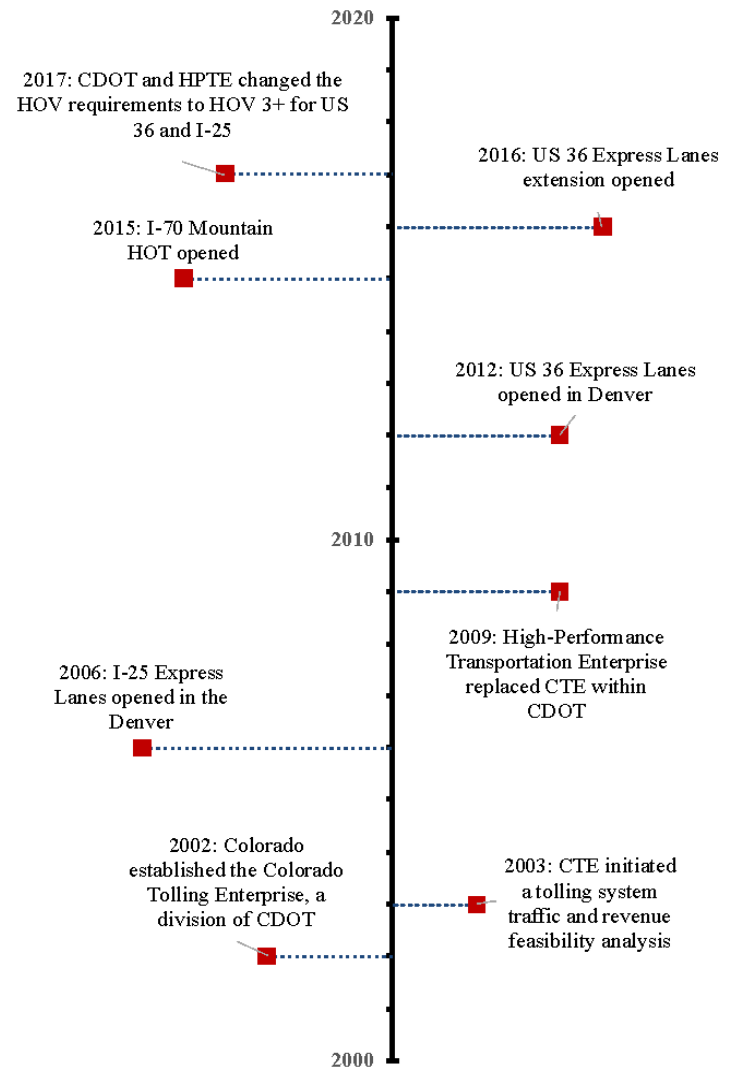

Figure 5: Colorado’s Initial Managed Lane Milestones traditional public sector design-bidbuild model.

In 2009, with gas tax revenue further on the decline due to inflation and the increasing use of fuel-efficient vehicles, the state of Colorado replaced the CTE with the High-Performance Transportation Enterprise (HPTE) through the state's Funding Advancements for Surface Transportation and Economic Recovery (FASTER) legislation. HPTE was tasked specifically to pursue public-private partnerships (PPPs) and other innovative financing mechanisms that could be used to more proactively address the state's growing congestion and capital improvements needs (CO Legislature 2009). HPTE was also created to help address Colorado's growing unemployment during the recession by providing jobs in construction through capital projects.

In 2012, with leadership from HPTE, CDOT opened its second HOT lane project in Denver on US-36 as a PPP. This project included building a new express lane in each direction and reconstructing the highway's existing pavement (Kenny 2013). Most recently, Colorado has used PPPs to open HOT lanes on I-70 and extend the US-36 HOT lanes. As of 2018, another 
HOT lane project was under construction on $\mathrm{C}-470$ and an additional project had been proposed for I-70 east (CDOT 2018).

\subsection{CALIFORNia}

California has since built over 200 roadway miles of toll-managed lanes in the state's three largest metropolitan areas. The first project was built in response to southern California's rapid population growth, and resulting congestion levels, in the 1980s. Caltrans proposed constructing HOV lanes on the congested freeway, SR-91, which connected, at the time, to rapidly growing areas of Riverside and Orange Counties (Gómez-Ibáñez and Meyer 1993). The project was stalled, however, due to controversy over HOV lanes, and its funding was eventually redirected to other projects (Build America Bureau 2014).

In 1989, the California legislature enacted AB 680, which authorized Caltrans to enter into agreements with private entities for the construction of up to four highway demonstration projects throughout the state and required that at least one project be located in southern California and one project in northern California (CA Legislature 1989). The bill allowed private entities to identify, construct and charge tolls on privately constructed facilities. As a result, private investors organized the California Private Transportation Company (CPTC) which proposed to Caltrans to construct the planned SR-91 HOV lanes as express toll lanes under the new legislation. CPTC and Caltrans negotiated a buildtransfer-operate franchise agreement for the project, which was awarded in December 1990. Construction of the new lanes began in 1993 and the new facility opened to traffic in December 1995 (Build America Bureau 2014). Following the success of SR-91, San Diego Association of

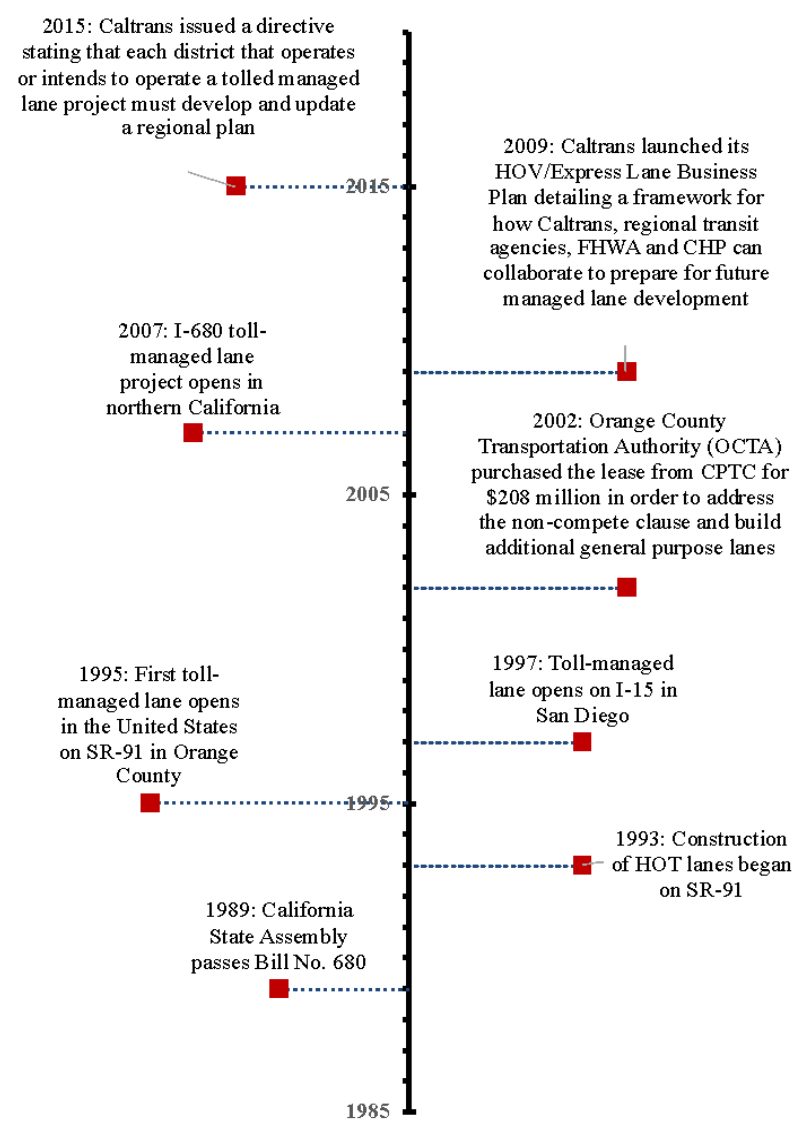

Figure 6: California’s Initial Managed Lane Milestones Governments (SANDAG) converted HOV facilities on I-15 to HOT lanes in 1996, which became the second HOT lane project in the US.

California's third HOT lane project was another of the projects selected under the AB 680 demonstration program, and the only selected project in northern California (Gómez-Ibáñez and Meyer 1993). This 85-mile HOT lane project, which opened in 2007, connects south San Francisco with south Sacramento along I-680 (Alameda County Transportation Commission 2013). Between 2005 and 2012, both SANDAG and Orange County Transportation Authority (OCTA) extended HOT facilities on both SR-91 and I-15. 
With congestion continuing to increase throughout California's urban regions and with the overall success of HOT lanes, Caltrans adopted its HOV/Express Lane Business Plan in 2009, to provide local transportation agencies "the direction and flexibility needed to aggressively initiate innovative congestion management strategies." This plan, which was developed in collaboration with regional transit authorities, FHWA, and California Highway Patrol (CHP), outlined a framework for 2009 through 2011 to guide the development of HOV lanes and tolled managed lanes throughout the state. Specifically, the business plan provided direction, "on those aspects of HOV and express lane development and operations that can and should be addressed at a state level to increase California's ability to manage congestion with HOV and express lanes" (Caltrans 2009).

This business plan differed from the plans of other states, such as Minnesota and Colorado, in that it detailed a framework for providing regional agencies with the support and flexibility they needed to pursue congestion management projects and PPPs, rather than just a specific list of promising target conversion facilities. In May 2015, Caltrans issued a directive stating that all districts, along with their regional transit agencies, that currently operate or expect to operate toll-managed lane facilities must develop a Managed Lanes System Plan, which must be updated every two years. Of the five states discussed in this paper, only California requires its districts to prepare planning documents. As of 2014, Caltrans reported that there are 1,700 roadway miles of HOT lanes proposed or planned by both Caltrans and regional agencies (Rouse 2015). Additionally, in just the last few years, managed lanes have become operational on parts of SR 237 and I-880 in northern California as well as on the I-10 and I-110 in the Los Angeles County. As of 2017, there were also 50 miles of HOT lanes under construction (see Appendix A). ${ }^{9}$

\section{DiscuSsion}

\subsection{Toll Managed Lane Motivation}

These five states became early adopters of toll-managed lanes because of persistent congestion and significant budget shortfalls. Between 1990 and 2000 all five of these states experienced significant population increases. Indeed, this decade was the largest census-to-census increase in population in America's history. California had the largest population growth during this time period, followed by Texas. While Florida's population increased in tandem with the overall United States, the state is the fourth most populated state and is only preceded by California, New York, and Texas (US Census Bureau 2001).

These population characteristics resulted in the congestion challenges these states faced in the early 2000s and coincided with the introduction of the toll-managed lanes concept. Between 2000 and 2016, all of the case study states continued to experience population increases ${ }^{10}$ and near or above average increases in total highway vehicle miles travelled (VMT). In this same period, three of the five states saw near or above average increases in VMT per capita (see Figure 7). This growth translates into more drivers driving more vehicles on U.S. highways, thus increasing congestion.

\footnotetext{
9 See Rouse (2015) for a more detailed list of all managed lanes projects happening in the state.

${ }^{10}$ Between 1990 and 2010, California experienced an 18.8 percent increase in population, Texas and Florida each experienced 30.1 percent increase, Colorado experienced 32.6 percent increase, and Minnesota experienced 19.3 percent increase (US Census Bureau 2001).
} 
Naturally, these trends in population and VMT growth are reflected in the urban congestion data. For instance, California, Texas, Florida, and Colorado are still home to more than a third of America's 25 most congested cities (see, e.g. INRIX 2018). Unsurprisingly, cities in California (i.e. Los Angeles, San Francisco, San Diego), Texas (i.e. Dallas, Houston, and Austin), and Florida (i.e. Miami, Orlando, and Tampa) are all major regions for tollmanaged lane development. The same can be said for Colorado (Denver) and Minnesota

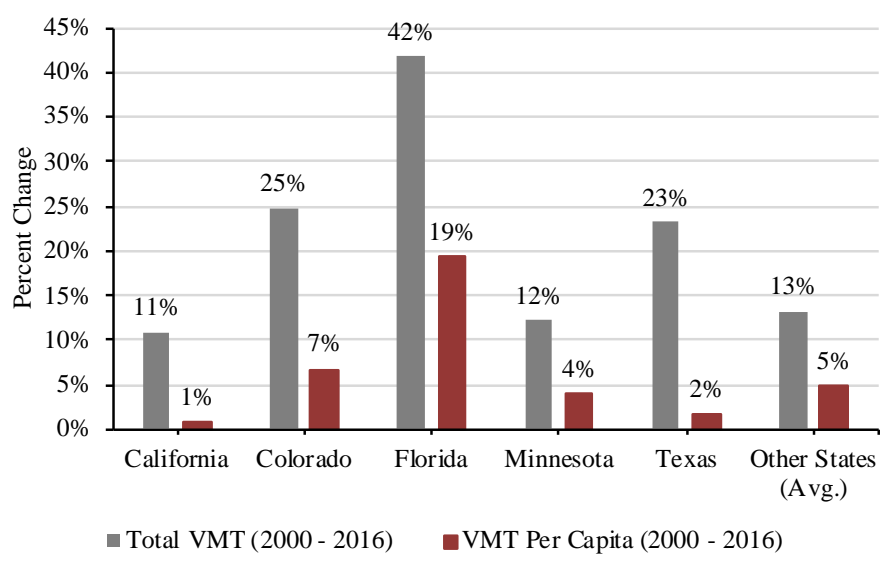

Figure 7: Change in Total VMT and VMT per Capita (Tax Policy Center 2018) (Minneapolis).

Stagnant gas tax rates in each of the pioneer states limited the ability of governments to collect enough revenue for transportation projects that would mitigate growing congestion. Between 2000 and 2009, none of the gas tax rates increased in any of the pioneer states (Tax Policy Center 2018). Even though revenue from gas taxes are the primary source of transportation funding, states have generally had difficulty increasing gas tax rates. This is not a partisan challenge either (see Figure 8). Democrat-leaning states (California, Minnesota), Republican-leaning (Texas, Florida), and "purple" states (Colorado) have experienced relatively similar gas tax rate trends (Pew Research Center 2014).

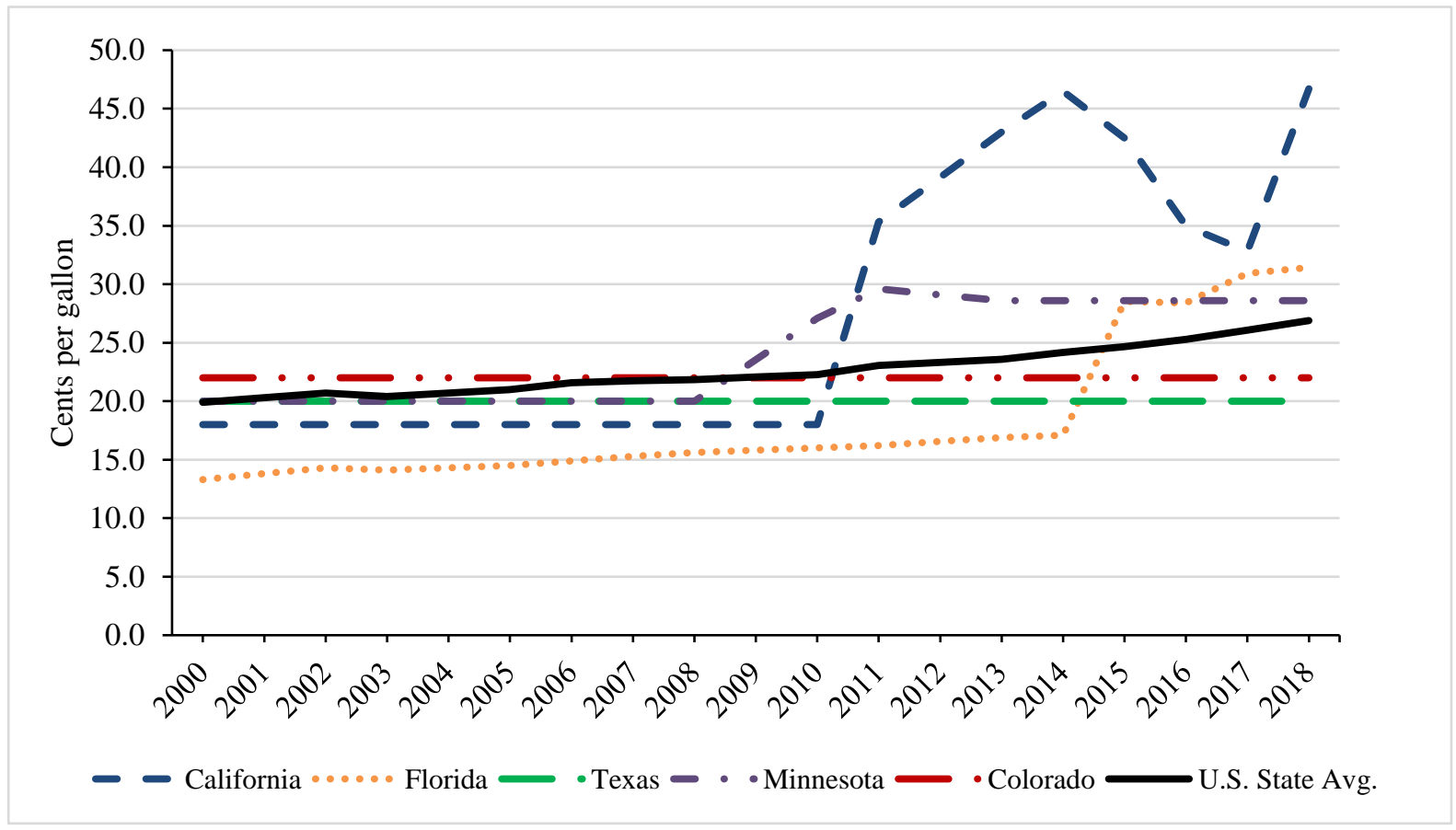

Figure 8: Gas Tax Rates in Each Pioneer State, 2000 - 2018 (Tax Policy Center 2018)

Stagnation of gas tax rates in each of these pioneer states offered further motivation for state governments to explore new, alternative financing methods for transportation projects. This delta between "need" and "ability" is evidenced by Florida's gas tax rate. Despite being one of 
the fastest growing and most congested states, Florida's gas tax ranked between the $47^{\text {th }}$ and $50^{\text {th }}$ lowest rate in the United States in the early 2000s at 14 cents per gallon. In 2007, Florida began steadily increasing its gas tax rate and its current rate (31 cents per gallon) now hovers in middle of the state rankings. However, the delayed revenue gains from Florida's gas tax increases remain insufficient to cover the state's full array of transportation needs. This is just one reason why Florida has pursued toll managed lanes so aggressively.

Similar observations can be made for Colorado and Texas. Neither Colorado nor Texas have increased their state gas tax rates. ${ }^{11}$ For Texas, this provides important context for the state's prolific use of toll managed lanes in Houston, Dallas, Ft. Worth, and now Austin to fund highway capacity projects and manage congestion. For Colorado, this also indicates toll managed lanes are being used primarily as a method for revenue generation, with secondary benefits coming from congestion relief. At the opposite end of the spectrum, California increased its state gas tax rate by 96 percent in 2011 from 18 cents per gallon to 35 cents per gallon. Since 2011, its rate has steadily increased and is now 48 cents per gallon, making it one of the highest tax rates in the country. Given the intensity of California's growth in the last two decades, this increase correlates to the state's burgeoning needs for transportation investments.

\subsection{TOLL MANAGEd LANE IMPLEMENTATION}

Although the nuances of toll-managed lane adoption differ slightly by state, the implementation process was similar. In all instances, the state transportation agencies conducted feasibility studies to determine which facilities were candidates for tolling and for toll-managed lanes specifically. However, these studies differ in size and scope. While Colorado conducted a statewide traffic and revenue feasibility analysis to identify potential toll projects, other states like Texas and California used corridor studies to identify congested routes within their large transportation networks. Additionally, both Florida and Colorado created new tolling "enterprises" within their state transportation agencies to lead the analysis and implementation of tolling projects. California had already gained experience with SR-91, but the other states implemented pilot toll-managed lane projects--including the Katy Freeway in Texas, I-95 in Florida, I-394 in Minnesota, and I-25 in Colorado-whose success spurred them to pursue additional projects (FHWA 2015).

However, the degree to which states have incorporated toll-managed lanes into their longterm transportation planning varies. Most of the five pioneer states are implementing tollmanaged lane projects on a case-by-case basis. But some states, notably Florida and Minnesota, have drafted regional toll-managed lane studies to identify facilities best suited for these facilities; so far, however, few of the projects identified in these studies have been implemented (FDOT 2019 ;MDOT 2017. Although Colorado lacks a state-wide toll-managed lane agenda, it has systematically expanded its HOT lane facilities across the Denver region. California is unique in that the highways are primarily managed at the regional level by regional transportation agencies in conjunction with the state transportation agency. State legislation has enabled these regional agencies to pursue toll-managed lane projects, which all the large urban areas are doing. However, each regional agency is required to report its managed lane projects (either implemented or planned) to the state agency. Texas is similar to California in its use of regional transportation agencies to manage state highways and these agencies are able to pursue HOT lane projects. Unlike California, however, Texas does not have a state-wide reporting requirement. Further, each urban area in Texas - Dallas/Ft. Worth, Houston, and Austin - is financing and managing its toll-managed lane projects differently.

\footnotetext{
11 The gas tax in Texas has not increased since 1991.
} 


\section{ConClusions}

Overall, many transportation planners across the United States are starting to embrace tollmanaged lanes as 1) an effective ADM technique to squeeze more capacity out of existing expressways and 2) as a politically palatable means of financing the construction of new highways in congested urban settings. As utilization of toll-managed lanes continues to grow, public officials will look to the early adopters of toll-managed lanes for guidance and insight. In this paper, we examined the adoption and utilization of toll-managed lanes in five pioneer states-Texas, Florida, Minnesota, Colorado, and California-in order to understand how these states embraced the toll-managed lane concept. While it is hazardous to broadly generalize about toll-managed lane adoption from only five US states, our case analysis is one of the first to highlight economic, political, and social factors motivating the adoption of tollmanaged lanes. First, toll-managed lane utilization appears to be driven by a combination of factors, including rapid population growth, growing urban congestion, and insufficient gas tax funding for transportation investments. Second, toll-managed lanes adoption is generally predicated on the passage of state legislation as well as FHWA authorization to toll sections of the interstate system. Additionally, although the nuances of enabling legislation for tollmanaged lanes differed between jurisdictions, the implementation process was generally similar across states. For example, in all instances, state transportation agencies conducted feasibility studies in order to determine which corridors were viable for toll-managed lane facilities. However, the size and scope of these studies differed from state to state. Finally, although these five states used similar means to instigate toll-managed lane utilization, the degree to which toll-managed lanes were integrated into the long-term transportation planning of each state varied wildly. This last result indicates that future work should give careful consideration to the transferability of toll-managed lane best practices across state lines. Moreover, more research is needed on the localized development of institutions enabling tollmanaged lane adoption, utilization, coordination, and management.

\section{FUNDING}

This study was funded in part by the United States Department of Transportation (USDOT) through the New England Region University Transportation Center at the Massachusetts Institute of Technology (MIT).

\section{REFERENCES}

Alameda County Transportation Commission. 2013. "The Southbound Interstate 680 (I-680) Express Lane Performance Evaluation: An After Study." Report to the Commission by Kittelson and Associates, Inc.

Buckeye, Kenneth R. and Lee W. Munnich, Jr. 2006. "Value Pricing Education and Outreach Model I-394 MnPASS Community Task Force." Transportation Research Record:

Journal of the Transportation Research Board, no. 1960: 80-86.

Buckeye, Kenneth. 2012. "Performance Evaluation of I-394 MnPASS Express Lanes in Minnesota." Transportation Research Record: Journal of the Transportation Research

Board 2278, no. 1: 153-162.

Buckeye, Kenneth. 2014. "Express Lane Performance Evaluation: I-35W in Minnesota."

Transportation Research Record: Journal of the Transportation Research Board 2450

(Revenue, Finance, Pricing and Economics): 36-43

Barton, Eric. 2014. "Florida's Toll Lane Boom." Florida's Center for Investigative

Reporting.

Build America Bureau. 2014.“SR-91 Express Lanes, Orange County, CA.” Washington, DC:

U.S. Department of Transportation. 
California Department of Transportation (Caltrans). 2009. "California HOV/Express Lane Business Plan, 2009." Prepared by Kimley-Horn and Associates Inc.

Caltrans. 2015. "Deputy Directive: Managed Lane Facilities." Directive Number DD-43-R1. May 29.

California (CA) Legislature. 1989. “Assembly Bill No. 680." Secretary of State of California.

Central Texas Regional Mobility Authority (CTRMA). 2019. "Interactive Regional Map." Austin, TX: CTRMA.

Colorado Department of Transportation (CDOT). 2005. "Colorado Tolling Enterprise; Statutory Requirements." Presentation: High Performance Transportation Enterprise.

CDOT. 2018. "Express Lanes." Colorado Department of Transportation.

Colorado Legislature. 2009. "Senate Bill No. 09-108: Funding Advancement for Surface Transportation and Economic Recovery Act." Secretary of State of Colorado.

Colorado Tolling Enterprise (CTE). 2005. "Colorado Statewide Tolling Enterprise, Fiscal Year 2005 Annual Report." Colorado Department of Transportation (CDOT).

CTE. 2004. "CTE Preliminary Traffic and Revenue Study." Prepared by Wilbur Smith Associates. Colorado Department of transportation.

Federal Highway Administration (FHWA). 2012. "Price Managed Land Guide." Washington, DC: US Department of Transportation.

Ellis, David, Brianne Glover, Curtis Beaty, Nick Norboge, Allison Weldon, Jeff Borowiec, Tim Lomax, and David Schrank. 2014. "Texas Toll Road Primer." Transportation Policy Research Center: Texas A\&M Transportation Institute.

FDOT. 2010. "2010 I-95 High Occupancy Vehicle Lane Monitoring Report.” Prepared by Cambridge Systematics, Inc. with Kimley-Horn and Associates, Inc.

FDOT. 2011. "95 Express Annual Report: Covering July 1, 2010 through June 30, 2011."

District Six, Florida Department of Transportation.

FDOT. 2013. "95 Express Annual Report: Covering July 12011 through June 30, 2012."

District Six, Florida Department of Transportation.

FDOT. 2019. "Florida Express Lanes." Florida Department of Transportation.

FHWA. 2010. "MnPASS Express Lanes - I-394, Minneapolis, HOV to HOT Conversion

Project." Washington, DC: U.S. Department of Transportation.

FHWA. 2015. "Contemporary Approaches in Congestion Pricing: Lessons Learned from the National Evaluation of Congestion Pricing Strategies at Six Sites." Report FHWA-JPO2015-217. Washington, DC: US Department of Transportation.

FHWA 2016a. "Report on Highway Public-Private Partnership Concessions in the United

States." BATIC Center and Office of Innovative Program Delivery, US Department of

Transportation.

FHWA. 2016b. "Federal-Aid Highway Program Guidance on High Occupancy Vehicle Lanes." Washington, DC: US Department of Transportation.

FHWA. 2017a. "Considerations for HOV Lane to HOT Lane Conversion Guidebook."

Washington, DC: US Department of Transportation.

FHWA. 2017b. "Active Demand Management." Washington, DC: US Department of Transportation.

FHWA. 2017c. "Priced Managed Lane Guide: Appendix: Priced Managed Lane Profiles."

U.S. Department of Transportation.

FHWA. 2017d. "Highway Statistics, annual editions." Washington, DC: US Department of Transportation.

Fitch Ratings. 2018. "Peer Review of U.S. Managed Lanes: Attribute Assessments and Ratings." Global Infrastructure and Project Finance.

Goodin, Ginger, Robert Benz, Mark Burris, Marcus Brewer, Nick Wood, and Tina Geiselbrecht. 2013. "Katy Freeway: An Evaluation of a Second-Generation Managed 
Lanes Project," Texas A\&M Transportation Institute, The Texas A\&M University System, College Station, Texas.

Gomez-Ibanez, José A., and John R. Meyer. 1993. Going Private: The International

Experience with Transport Privatization. Washington, DC: The Brookings Institution.

Hannan, Larry. 2012. "Transportation secretary: Tolls are the road to Florida's future." The Florida Times-Union.

INRIX. 2018. Global Traffic Scorecard.

IPFS. 2016. "Florida's Turnpike Enterprise."

Kenny, Harris. 2013. "Using Innovative Policy Tools to Rebuild Colorado's Infrastructure." Reason Foundation.

Kuhn, Beverly, Ginger Goodin, Andrew Ballard, Marcus Brewer, Robert Brydia, Jodi Carson, Susan Chrysler et al. 2005. "Managed Lanes Handbook." Texas Transportation Institute, The Texas A\&M University System, College Station, Texas.

Minnesota Department of Transportation (MnDOT). 2005. "MnPass System Study, Final Report." Prepared by Cambridge Systematics with URS Corporation.

MnDOT. 2010. "MnPass System Study Phase II." Prepared by Cambridge Systematics.

MnDOT. 2017. "MnPass System Study Phase III." Minnesota Department of Transportation.

North Texas Tollway Authorit (NTTA). "Milestones." TxDOT.

Poole, Robert. 2014. "Keys to Financing Managed Lane Networks." Reason Foundation.

Rouse, Joe. 2015. "Managed Lanes in California: Where We've Been Where We're Going." Presentation: California Department of Transportation.

Sanchez, Ricardo. July 2016. "NTE/LBJ Managed Lanes Facts and Benefits.” Slide presentation.

Tax Policy Center. 2018. "State Motor Fuels Tax Rates." Washington, DC: Urban Institute and Brookings Institution.

Transportation Research Board (TRB). 2019. "Project Database - Managed Lanes." Washington, DC; TRB.

Transport for America. 2018. State Transportation Funding: The states successfully raising new transportation revenue. Washington, DC: Transport for America.

US Department of Transportation (USDOT). 2013. "Urban Partnership Agreement: Minnesota Evaluation Report." Research and Innovative Technology Administration, Federal Highway Administration. FHWA-JPO-13-048.

US Census Bureau. 2001. "Population Change and Distribution, 1990 - 2000."

Whetsell, Travis A., and Patricia M. Shields. 2015. "The dynamics of positivism in the study of public administration: A brief intellectual history and reappraisal." Administration \& Society47, no. 4: 416-446.

Williamson, Richard. 2010. “Texas Coalition Sets Its Sights on \$8.7B of Transportation Funding." Bond Buyer; New York, N.Y.

Williamson, Richard. 2013. "Time is Money for Managed Lanes in Texas," Bond Buyer, New York, N.Y.

Yin, Robert K. 2017. Case Study Research and Applications: Design and Methods. Sage Publications. 
APPEndix A: TOll-Managed Lanes Throughout the US

\begin{tabular}{|c|c|c|c|c|c|c|c|c|c|}
\hline \begin{tabular}{|l} 
U.S. TOLLED MANAGED LANE PROJECTS \\
\end{tabular} & & & & & & & & & \\
\hline NAME & STATE & REGION & FACILITY & STATUS & $\begin{array}{c}\text { CONSTRUCTION } \\
\text { TYPE }\end{array}$ & $\begin{array}{l}\text { NEW FACILITY/ } \\
\text { EXTENSION }\end{array}$ & $\begin{array}{l}\text { YEAR } \\
\text { OPENED }\end{array}$ & EXEMPTION & $\begin{array}{l}\text { ORIGINAL } \\
\text { OPERATOR }\end{array}$ \\
\hline SR 91 Express Lanes & $\mathrm{CA}$ & Orange County & SR-91 & Operational & New Lane & New Facility & 1995 & HOV $3+$ & Private \\
\hline I-15 Express Lanes & $\mathrm{CA}$ & San Diego County & I-15 & Operational & Conversion/New & New Facility & 1996 & HOV $2+$ & Public \\
\hline I-15 Express Lanes & $\mathrm{CA}$ & San Diego County & $\mathrm{I}-15$ & Operational & Conversion/New & Extension & 2012 & HOV $2+$ & Public \\
\hline MnPass Express Lanes & MN & Minneapolis & I-394 & Operational & Conversion & New Facility & 2005 & HOV $2+$ & Public \\
\hline I-25 HOV Exppress Lanes & $\mathrm{CO}$ & Denver & $\mathrm{I}-25$ & Operational & New Lane & New Facility & 2006 & HOV $2+$ & Public \\
\hline Katy Managed Lanes & $\mathrm{TX}$ & Harris County & I-10/US 59/US 290 & Operational & Conversion/New & New Facility & 2009 & HOV $2+$ & Public \\
\hline SR-167 HOT Lanes & WA & Seattle & SR-167 & Operational & Conversion & New Facility & 2008 & HOV $2+$ & Public \\
\hline 95 Express & $\mathrm{FL}$ & Miami-Dade, Broward, Palm Beach Counties & I-95 & Operational & Conversion/New & New Facility & 2008 & HOV $3+$ & Public \\
\hline 95 Express & $\mathrm{FL}$ & Miami-Dade, Broward, Palm Beach Counties & I-95 & Operational & Conversion/New & Extension & 2010 & HOV $3+$ & Public \\
\hline 95 Express & $\mathrm{FL}$ & Miami-Dade, Broward, Palm Beach Counties & $\mathrm{I}-95$ & Operational & Conversion/New & Extension & 2016 & HOV $3+$ & Public \\
\hline MnPass Express Lanes & MN & Minneapolis & $\mathrm{I}-35 \mathrm{~W}$ & Operational & Rebuild/Conversion/New & New Facility & 2009 & HOV $2+$ & Public \\
\hline I-680 Southbound Express Lanes & $\mathrm{CA}$ & Alameda County & $\mathrm{I}-680$ & Operational & Conversion & New Facility & 2010 & HOV $2+$ & Public \\
\hline I-15 Express Lanes & NV & Las Vegas & I- -15 & Operational & New Lane & New Facility & 2010 & HOV $2+$ & Public \\
\hline I-15 Express Lanes & UT & Salt Lake City & I-15 & Operational & Rebuild/New & New Facility & 2010 & HOV $2+$ & Public \\
\hline I-15 Express Lanes & UT & Salt Lake City & I-15 & Operational & Rebuild/New & Extension & 2012 & HOV $2+$ & Public \\
\hline I-15 Express Lanes & UT & Salt Lake City & I-15 & Operational & Rebuild/New & Extension & 2016 & HOV $2+$ & Public \\
\hline I-85 Express Lanes & GA & Metro Atlanta & $\mathrm{I}-85$ & Operational & Conversion & New Facility & 2011 & HOV $3+$ & Public \\
\hline SR-237 / I-880 Express Lanes & $\mathrm{CA}$ & Santa Clara County & SR $237 / \mathrm{I}-880$ & Operational & Conversion & New Facility & 2012 & HOV $2+$ & Public \\
\hline I-110 MetroExpress Lanes & $\mathrm{CA}$ & Los Angeles County & $\mathrm{I}-110$ & Operational & Conversion & New Facility & 2012 & HOV $2+$ & Public \\
\hline Metro HOT Lanes (IH 45 South Gulf) & $\mathrm{TX}$ & Harris County & I-45 & Operational & Conversion & New Facility & 2012 & HOV $2+$ & Public \\
\hline Metro HOT Lanes (IH 45 North Freeway) & $\mathrm{TX}$ & Harris County & I-45 & Operational & Conversion & Extension & 2012 & HOV $2+$ & Public \\
\hline Metro HOT Lanes & $\mathrm{TX}$ & Harris County & US 290 & Operational & Conversion & New Facility & 2012 & HOV $2+$ & Public \\
\hline Metro HOT Lanes (Southwest Freeway) & $\mathrm{TX}$ & Harris County & US 59 & Operational & Conversion & Extension & 2012 & HOV $2+$ & Public \\
\hline 495 Express Lanes & VA & Northern & I-495 & Operational & Rebuild/New & New Facility & 2012 & HOV $3+$ & Private \\
\hline US 36 Express Lanes & CO & Denver & US 36 & Operational & Rebuild/New & New Facility & 2012 & HOV $2+$ & Public \\
\hline US 36 Express Lanes & CO & Denver & US 36 & Operational & Rebuild/New & Extension & 2016 & HOV $2+$ & Public \\
\hline I-10 Metro ExpressLanes & $\mathrm{CA}$ & Los Angeles County & I-10 & Operational & Conversion & New Facility & 2013 & HOV $2+$ & Public \\
\hline 595 Express & $\mathrm{FL}$ & Broward & I-595 & Operational & New Lane & New Facility & 2014 & ETL & Public \\
\hline I-95 Express Toll Lanes & MD & Baltimore & $\mathrm{I}-95$ & Operational & Rebuild/New & New Facility & 2014 & ETL & Public \\
\hline NTE TEXPress Lanes & $\mathrm{TX}$ & Tarrant County & I-820 & Operational & New Lane & New Facility & 2014 & HOV 2+ disc & Private \\
\hline Metro HOT Lanes (North Eastex Freeway) & $\mathrm{TX}$ & Harris County & US 59 & Operational & Conversion & New Facility & 2014 & HOV $2+$ & Public \\
\hline 95 Express Lanes & VA & Northern & I-95 & Operational & Rebuild/New & New Facility & 2014 & HOV $3+$ & Private \\
\hline I-70 Mountain & CO & Denver & I-70 & Operational & Conversion & New Facility & 2015 & ETL & Public \\
\hline LBJ TEXPress Lanes & $\mathrm{TX}$ & Dallas County & $\mathrm{I}-635 / \mathrm{I}-35 \mathrm{E}$ & Operational & New Lane & New Facility & 2015 & HOV $2+$ disc & Private \\
\hline DFW Conntector TEXPress Lanes & $\mathrm{TX}$ & Dallas County & SH 114/SH 121 & Operational & New/Rebuild & New Facility & 2015 & HOV $2+$ disc & Public \\
\hline MnPass Express Lanes & MN & Minneapolis & I-35E & Operational & Conversion/New & Extension & 2016 & HOV $2+$ & Public \\
\hline I-580 Express Lanes & $\mathrm{CA}$ & Tri-Valley Corridor & I- -580 & Operational & Conversion & New Facility & 2016 & HOV $2+3+$ & Public \\
\hline I-30 TEXPress Lanes & $\mathrm{TX}$ & Dallas County & $\mathrm{I}-30$ & Operational & New Lane & New Facility & 2016 & HOV $2+$ disc & Private \\
\hline I-405 Express Toll Lanes & WA & Seattle & $\mathrm{I}-405$ & Operational & Rebuild/New & New Facility & 2016 & HOV $3+$ & Public \\
\hline I-580 Express Lanes Project & $\mathrm{CA}$ & San Diego County & I-580 & Operational & New Lane & New Facility & 2016 & Нот & Public \\
\hline I-680 SB and NB Express Lanes: Walnut Creek to San Ramon & $\mathrm{CA}$ & Contra Costa County & $\mathrm{I}-680$ & Operational & Conversion & Conversion & 2017 & НОт & Public \\
\hline MoPac Express & $\mathrm{TX}$ & Austin & Loop 1 & Operational & New Lane & New Facility & 2017 & ETL & Public \\
\hline 91 Project Fast Forward & $\mathrm{CA}$ & Riverside County & SR-91 & Operational & New Lane & Extension & 2017 & HOT & Public \\
\hline I-75 South Metro Express Lanes & GA & Metro Atlanta & I.75 & Operational & New Lane & New Facility & 2018 & ETL & Public \\
\hline 35Express TEXPress Lanes & $\mathrm{TX}$ & Dallas County & $\mathrm{I}-35 \mathrm{E}$ & Operational & New Lane & Extension & 2017 & ETL & Private \\
\hline Northwest Corridor Express Lanes & GA & Metro Atlanta & I-75 & Operational & New Lane & Extension & 2018 & ETL & Public \\
\hline NTE TEXPress Lanes & $\mathrm{TX}$ & Tarrant County & $\mathrm{I}-35 \mathrm{~W}$ & Operational & New Lane & Extension & 2018 & HOV $2+$ disc & Private \\
\hline Midtown TEXPress Lanes & $\mathrm{TX}$ & Dallas County & SH 183/114 & Operational & New/Rebuild & New Facility & 2018 & HOV $2+$ disc & Private \\
\hline I-30 TEXPress Lanes & $\mathrm{TX}$ & Dallas County & $\mathrm{I}-30$ & Operational & New Lane & Extension & 2017 & HOV $2+$ disc & Private \\
\hline I-85 Extension & GA & Metro Atlanta & I-85 & Operational & Conversion & Extension & 2018 & HOV $3+$ & Public \\
\hline I-580 Express Lanes: Tracy \& Livermore & $\mathrm{CA}$ & Tri-Valley Corridor & I- -580 & Proposed & New Lane & Extension & 2030 & НОт & Public \\
\hline I-680 Express Lanes: Between Fairfield and Benicia & $\mathrm{CA}$ & Solano County & I- -680 & Proposed & New Lane & Extension & 2030 & HOT & Public \\
\hline I-15 Corridor Project & $\mathrm{CA}$ & San Bernardino County & I-15 & Proposed & New Lane & Extension & 2024 & HOT & Public \\
\hline Northeast Florida Express Lanes & $\mathrm{FL}$ & Northeast Florida & $\mathrm{I}-95$ & Proposed & New Lane & Extension & N/A & ETL & Public \\
\hline Tampa Bay Next & FL & Tampa & $\mathrm{I}-75 / \mathrm{I}-275 / \mathrm{I}-4$ & Proposed & New Lane & New Facility & N/A & ETL & Public \\
\hline Georgia 400 Express Lanes & GA & Metro Atlanta & GA 400 & Proposed & New Lane & New Facility & 2024 & НОТ & Public \\
\hline I-55 Managed Lane Project & $\mathrm{IL}$ & Chicago & I-55 & Proposed & New Lane & New Facility & N/A & HOT & Private \\
\hline Route 3 Express Toll Lane & MA & N/A & Route 3 & Proposed & New Lane & New Facility & N/A & ETL & Private \\
\hline Northeast Florida Express Lanes & $\mathrm{FL}$ & Northeast Florida & I-295 & Proposed & New Lane & Extension & N/A & ETL & Public \\
\hline 635 East HOV/Express Lanes & $\mathrm{TX}$ & Dallas County & $\mathrm{I}-635$ & Proposed & New Lane & Extension & N/A & HOT & Private \\
\hline I-285 Eastside & GA & Metro Atlanta & $\mathrm{I}-285$ & Proposed & New Lane & New Facility & 2025 & & Public \\
\hline I-285 Westside & GA & Metro Atlanta & I-285 & Proposed & New Lane & New Facility & 2026 & & Public \\
\hline I-285 Top End & GA & Metro Atlanta & $\mathrm{I}-285$ & Proposed & New Lane & New Facility & 2028 & & Public \\
\hline I- 405 Express Lanes: SR 73 to I-605 & $\mathrm{CA}$ & Orange County & $\mathrm{I}-405$ & Under Construction & Rebuild/New & New Facility & 2023 & Нот & Public \\
\hline I-680 Northbound HOV/Express Lane Project & $\mathrm{CA}$ & Alameda County & I- -680 & Under Construction & New Lane & Extension & 2020 & HOT & Public \\
\hline I-485 Express Lanes & $\mathrm{NC}$ & Charlotte & I-485 & Under Construction & New Lane & New Facility & 2022 & НОТ & Public \\
\hline I-880 Northbound/Southbound Express Lanes & $\mathrm{CA}$ & Alameda County & $\mathrm{I}-880$ & Under Construction & Conversion & New Facility & 2020 & Нот & Public \\
\hline I-15 Express Lanes & $\mathrm{CA}$ & Riverside County & $\mathrm{I}-15 / \mathrm{SR}-60$ & Under Construction & New Lane & Extension & 2020 & HOV $3+$ & Public \\
\hline US 101 Express Lanes/Silicon Valley Express Lanes & $\mathrm{CA}$ & Santa Clara County & US-101 & Under Construction & Conversion/New & New Facility & 2021 & HOT & Public \\
\hline SR 85 Express Lanes/Silicon Valley Express Lanes & $\mathrm{CA}$ & Santa Clara County & SR-85 & Under Construction & Conversion/New & New Facility & 2021 & НОт & Public \\
\hline 1-80 Express Lanes: Emeryville to Fairfield & $\mathrm{CA}$ & Alameda County & I-80 & Under Construction & Conversion/New & Extension & 2021 & НОт & Public \\
\hline I-80 Express Lanes: Vacaville to Davis & $\mathrm{CA}$ & Solano County & $\mathrm{I}-80$ & Under Construction & New Lane & Extension & 2035 & НОТ & Public \\
\hline I-80 Express Lanes: Fairfield to Vacaville & $\mathrm{CA}$ & Solano County & I-80 & Under Construction & Conversion/New & Extension & 2021 & Нот & Public \\
\hline I-680 SB and NB Express Lanes: Benicia to Walnut Creek & $\mathrm{CA}$ & Contra Costa County & $\mathrm{I}-680$ & Under Construction & Conversion & Extension & 2021 & НОт & Public \\
\hline I-10 Corridor Project & $\mathrm{CA}$ & San Bernardino County & I-10 & Under Construction & New Lane & Extension & 2023 & HOT & Public \\
\hline I-70 East & $\mathrm{CO}$ & Denver & I-70 & Under Construction & Rebuild & Extension & 2022 & ETL & Public \\
\hline Northeast Florida Express Lanes & $\mathrm{FL}$ & Northeast Florida & $\mathrm{I}-295$ & Under Construction & New Lane & New Facility & 2019 & ETL & Public \\
\hline $1-66$ & VA & Beltway & $\mathrm{I}-66$ & Under Construction & Conversion/New & New Facility & 2022 & НОТ & Private \\
\hline Palmetto Express & $\mathrm{FL}$ & Miami Dade, Broward Counties & SR-826/I-75 & Under Construction & New Lane & New Facility & 2019 & ETL & Public \\
\hline I-77 Express Lanes & $\mathrm{NC}$ & Charlotte & I-77 & Under Construction & Conversion/New & New Facility & 2019 & НОТ & Public \\
\hline I-75 Express Lanes Project & $\mathrm{FL}$ & Miam-Dade County & I.75 & Under Construction & New Lane & Extension & 2019 & ETL & Public \\
\hline I-30 TEXPress Lanes (West) & $\mathrm{TX}$ & Dallas County & $\mathrm{I}-30$ & Under Construction & New Lane & Extension & 2020 & HOV 2+ disc & Private \\
\hline I-805 Express Lanes Project & $\mathrm{CA}$ & San Diego County & I-805 & Under Construction & New/Rebuild & New Facility & 2020 & Нот & Public \\
\hline C -470 & $\mathrm{CO}$ & Denver & C- -470 & Under Construction & New Lane & New Facility & 2019 & HOV $2+$ & Public \\
\hline I-4 Ultimate & $\mathrm{FL}$ & Central Florida & $\mathrm{I}-4$ & Under Construction & Rebuild & New Facility & 2021 & ETL & Public \\
\hline SR-237 Phasse 2 & $\mathrm{CA}$ & Santa Clara County & SR 237 & Under Construction & Conversion & Extension & 2019 & HOV $2+$ & Public \\
\hline & & & & & & & & & \\
\hline
\end{tabular}

